\title{
Commercial building flooring failure caused by swelling of the foundation layers
}

\author{
Stawomir Kwiecien ${ }^{1, *}$ \\ ${ }^{1}$ Department of Geotechnics and Roads, Faculty of Civil and Environmental Engineering, Silesian \\ University of Technology, Akademicka 5, 44-100 Gliwice, Poland
}

\begin{abstract}
The work describes the damage, testing and method of repairing the flooring. The flooring formed part of a commercial pavilion covering an area of approx. $1200 \mathrm{~m}^{2}$. Significant damage in the form of cracks and elevations of up to a height of almost $80 \mathrm{~mm}$ were detected in the flooring. Geodetic, laboratory and geotechnical tests were carried out to determine the causes of the damage. The cause was found to be swelling of the floor base course layers, consisting of embankments made of unburnt colliery shale mixed with ashes. The swelling processes ceased about 5 years after the structure was commissioned.
\end{abstract}

\section{Introduction}

The floor and its wearing layer together form one of the most important elements of the building finish, ensuring proper operation throughout the planned period of use. Despite many years of experience and the use of advanced technologies, concrete flooring still feature a disproportionately high rate of damage and defects [1-3]. For contractors, this is usually a serious problem during site acceptance, with frequent complaints during the warranty periods. Most flooring defects are observed in the initial period of use, or even immediately after the completion of the flooring works. Flooring damage repairs are usually cumbersome, costly and have an impact on the aesthetics and future operation of the structures. Damage to the flooring is most often caused by manufacturing errors and contraction of the concrete base, and less often by inadequate ground substrate preparation [3-5].

This article describes an example of flooring damage in a commercial pavilion. The damage occurred as a result of unsuitable aggregate being used for the flooring foundation.

\section{Structure and flooring description}

The commercial pavilion building in which the flooring damage occurred has two aisles, with clear spans between walls of 19.69 and $5.5 \mathrm{~m}$. The larger aisle houses a sales room, while the smaller aisle is used as a storage room. The smaller aisle is shorter than the larger aisle by approx. $15.3 \mathrm{~m}$, to accommodate the driveway and supply area. The total building surface area is $1278.7 \mathrm{~m}^{2}$, the usable area is $1173.56 \mathrm{~m}^{2}$, the sales area with vestibule is $687.8 \mathrm{~m}^{2}$, the

\footnotetext{
${ }^{*}$ Corresponding author: slawomir.kwiecien@polsl.pl
} 
structure height is $5.67 \mathrm{~m}$, and its volume is $7096 \mathrm{~m}^{3}$. The plan of the structure is shown in Fig. 1.

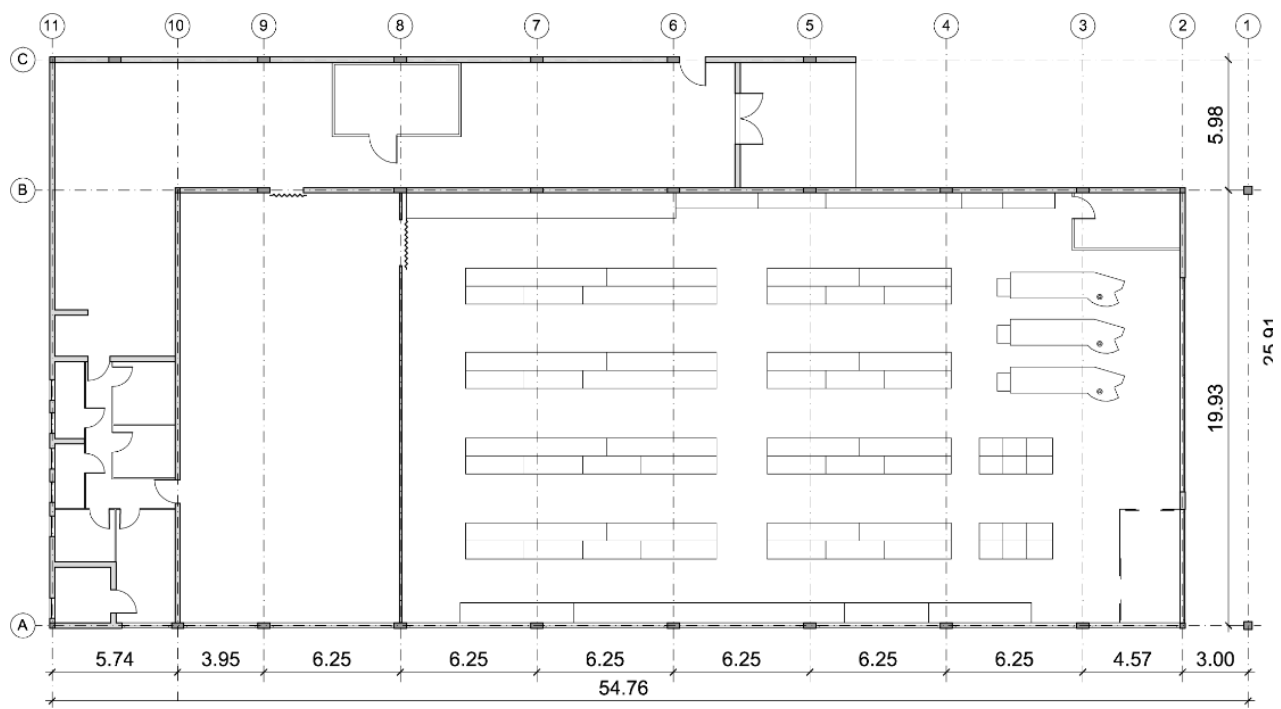

Fig. 1. Building plan.

Geotechnical tests were carried out prior to the construction of a food discount store. It was found that down to the depth of $4 \mathrm{~m}$ below ground level the ground substrate consists of soils that differ in lithology and genesis. The youngest formations in the soil of the area in question are contemporary made ground. They appear as a continuous layer of varying thickness, of approx. 1 to almost $3 \mathrm{~m}$. Lithologically, they are mixtures of different-grained sands with cohesive material, debris and fine coal. Within the embankments are old concrete and calcareous foundations of demolished structures. There is a continuous layer of residual soil and Carboniferous rocks below the embankments. Coherent residual soils are represented by semi-solid and solid clay, as well as sandy clay and silty clay. Soft rocks (silts locally layered with mudstones) were bored to below the residual soil layers. The Carboniferous material was not drilled down to the depth of recognition of the material there. Therefore, it was recommended to remove the made ground and fill the resulting cavities with compacted (up to density $I_{D}=50 \%$ ) sand or gravely sand. It was also recommended to remove the remains of old structures under the planned foundations and fill the resulting cavities with sand or gravely sand.

Foundations of reinforced concrete footings of cross-sectional dimensions $50 \times 150 \mathrm{~cm}$ and $50 \times 100 \mathrm{~cm}$ were designed for the substrate prepared in such a way. The footing foundation level is $-1.2 \mathrm{~m}$ and $-2.45 \mathrm{~m}$ (in the unloading ramp area).

The outer walls of the building was designed as three-layer, $49.5 \mathrm{~cm}$-thick walls. The supporting layer for the walls comprise sand and lime elements on a regular cement and lime mortar. The next layers are: $12 \mathrm{~cm}$ thermal insulation of mineral wool, air void of $4 \mathrm{~cm}$ and clinker brick of $9 \mathrm{~cm}$. The longitudinal supporting inner wall was made of silicate elements. Reinforced concrete cores with a rectangular cross-section of $24 \times 56 \mathrm{~cm}$ were designed under roof trusses with additional square cores having a side length of $24 \mathrm{~cm}$ on transverse walls to support the roof structure elements and reinforce the walls. It was recommended to connect the wall of silicate elements with cores using toothings and with rods of $6 \mathrm{~mm}$ in diameter at every second support joint. The walls were topped with a reinforced concrete rim. 
The structure is covered with a gable roof with a pitch of $5 \%$. The roof structure over the wider aisle was designed as prefabricated pre-stressed concrete girders. Above the narrower aisle the roof structure was designed as steel HEA 260 beams fixed to the girder front.

The flooring was designed as a $20 \mathrm{~cm}$-thick reinforced concrete slab (C20/25), reinforced with a grid of $10 \mathrm{~mm}$-diameter bars with a mesh of $15 \times 15 \mathrm{~cm}$ (steel yield strength of $500 \mathrm{~N} / \mathrm{mm}^{2}$ ). The flooring slab was designed on a layer of $0.2 \mathrm{~mm}$ thick PE foil and thermal insulation made of $6 \mathrm{~cm}$-thick foamed polystyrene.

It was recommended to make the foundation of aggregate condensed with $25 \mathrm{~cm}$-thick layers, density index $\mathrm{I}_{\mathrm{s}} \geq 0.98$, under the EPS. It was recommended to carry out a soil compaction test on each layer and the substrate load-bearing capacity tests directly under the flooring. The minimum secondary deformation modulus is $E_{2} \geq 100 \mathrm{~N} / \mathrm{mm}^{2}$. It was recommended to thicken the native soil to obtain the load-bearing parameters. The minimum secondary deformation modulus is $E_{2} \geq 100 \mathrm{~N} / \mathrm{mm}^{2}$. Moisture insulation of a foil or heatweldable membrane was designed for the reinforced concrete slab, two layers of PE foil and flooring layers. The top layer of the flooring was made of ceramic tiles.

\section{Damage}

After the structure was commissioned, the following damage and irregularities in the finishing elements of the commercial pavilion were found: wall cracks, floor cracks and unevenness of the flooring, damage to the suspended ceiling and displacement of the door to the storage part. Cracks were found on the structural walls. The cracks were diagonal (stepped) and vertical. The stepped cracks usually occurred near the centre of the wall length (shrinkage of the wall $[6,7]$ ), while vertical cracks were at the junction of the reinforced concrete cores with the masonry wall. There were also typical cracks under the windows [8] and at the lintels [9]. The crack openings were up to $0.5 \mathrm{~mm}$ and were partially repaired by filling with mortar. The repaired cracks did not open again. The crack view is shown in Fig. 2 and 3. Damage was also detected in the non-load-bearing wall of the room located at the ticket office, made of plastic. A fracture was found at the door to this room (Fig. 4).

a)

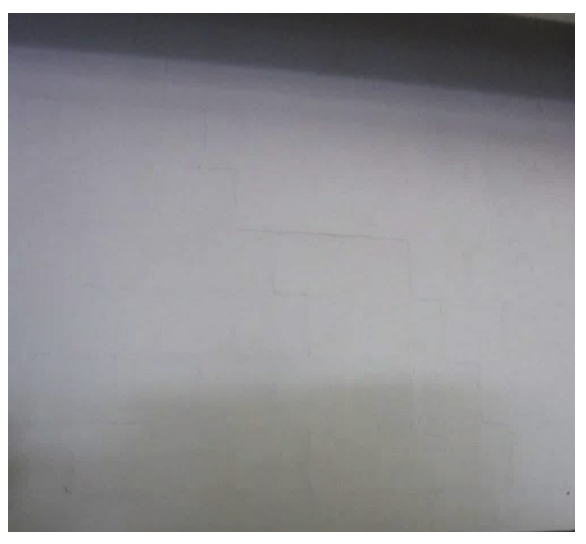

b)

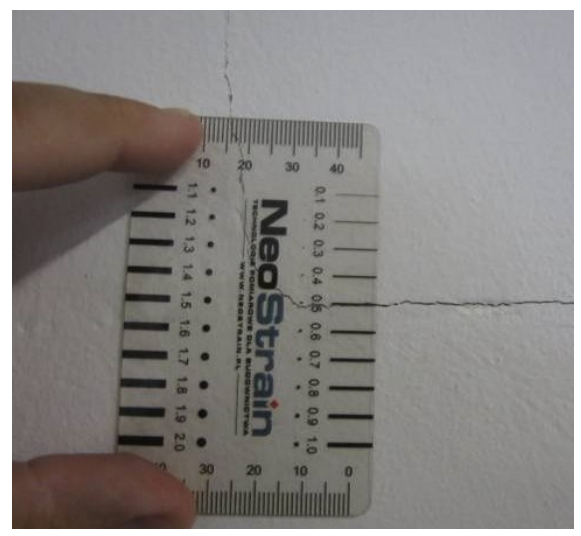

Fig. 2. An example of cracking of the load-bearing wall between the storage room and the sales section: a) view, b) crack opening measurement. 


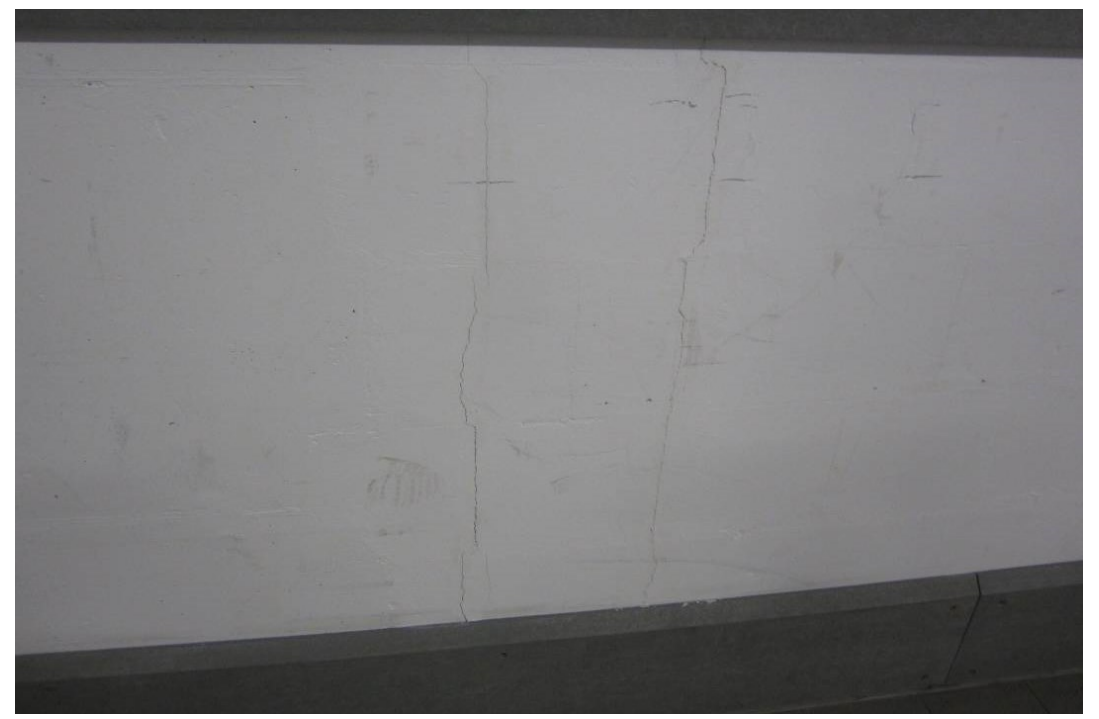

Fig. 3. Cracking at the junction of reinforced concrete core and wall.

a)

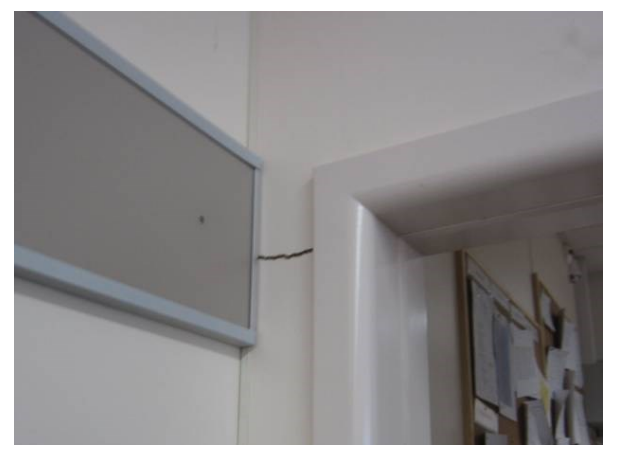

b)

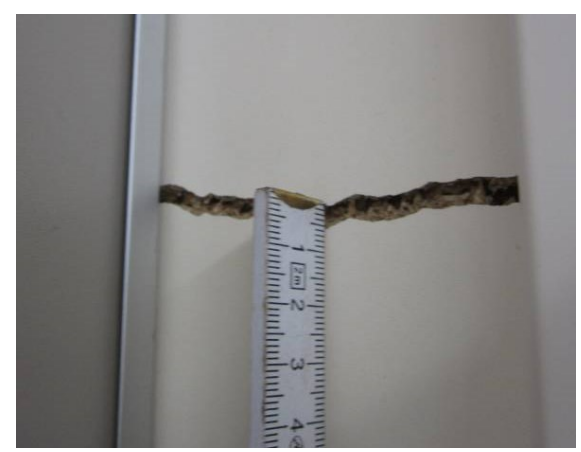

Fig. 4. Cracking of the non-load-bearing wall of the store manager's room: a) view, b) crack measurement.

The inspection showed damage to the flooring. The following were found: slope of the flooring of up to $1.7^{\circ}$, i.e. approx. $30 \mathrm{~mm} / \mathrm{m}$ (Fig. 5), cracks on the surface of ceramic tiles (Fig. 6) and tearing of expansion gap filling (Fig. 7).

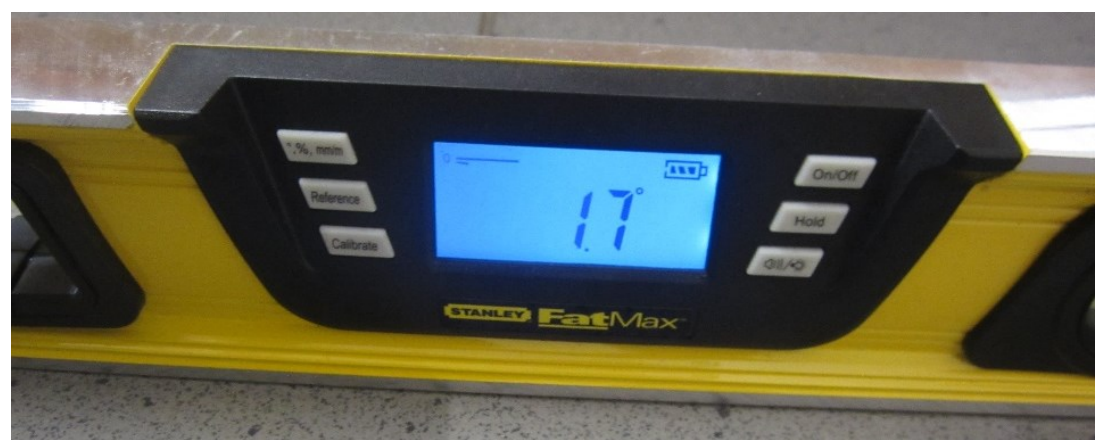

Fig. 5. Local slope of the flooring. 


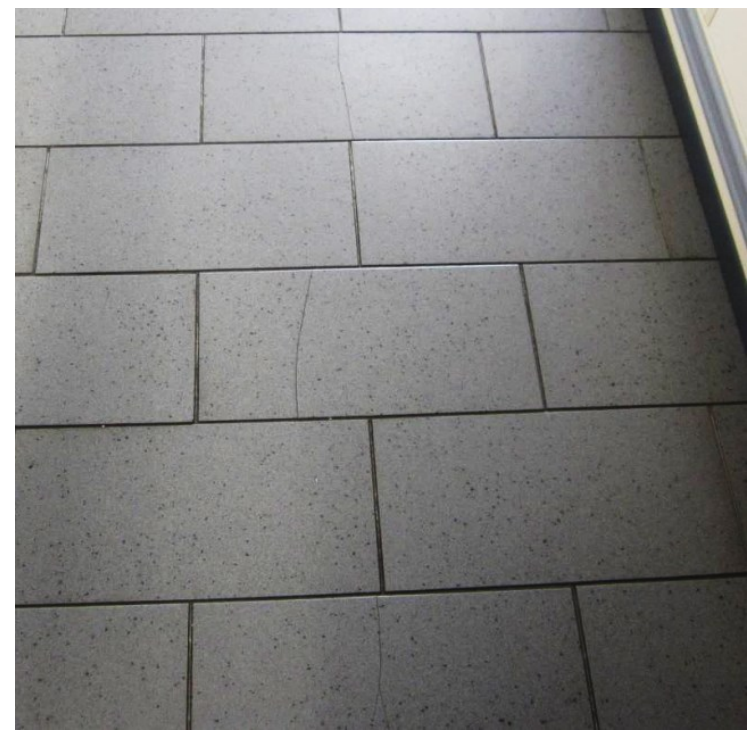

Fig. 6. Cracked flooring.

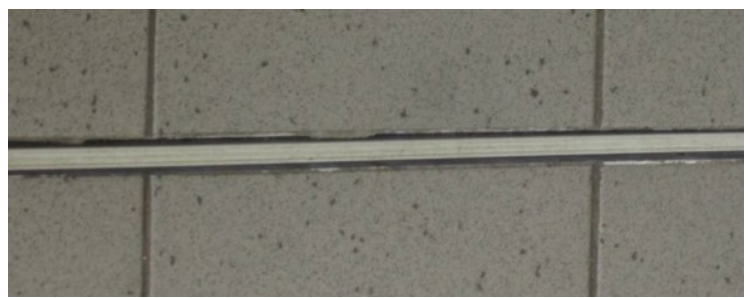

Fig. 7. Tearing of expansion gap.

In addition, ceiling damage in the form of deformation was found. The damage occurred in the sales room and in the store manager's room (Fig. 8). The locations of the structural damage are shown in Fig. 9.

a)

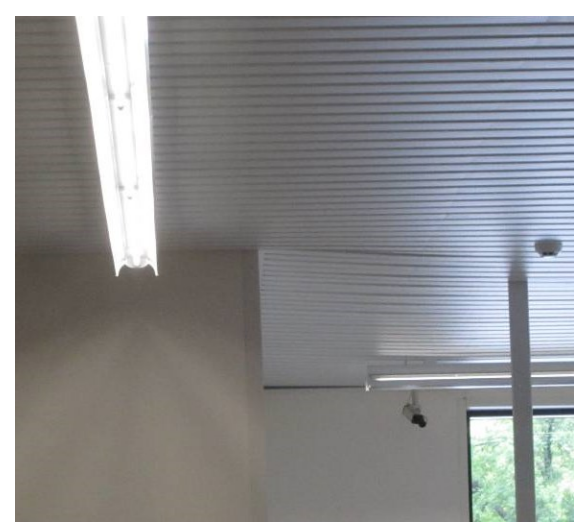

b)

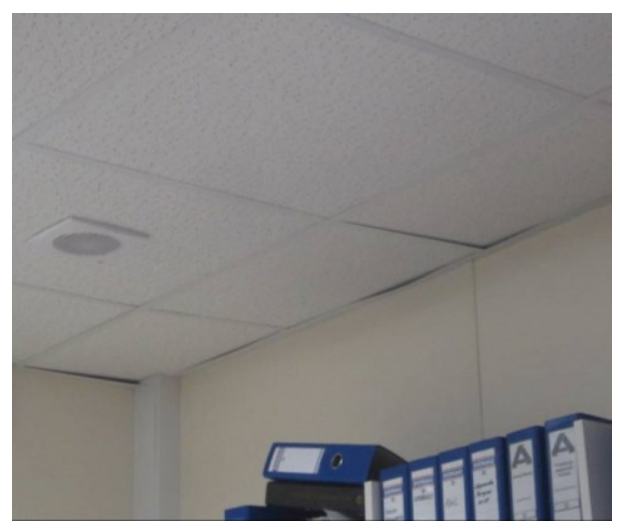

Fig. 8. Cracking of the non-load-bearing wall of the store manager's room: a) view, b) crack measurement. 


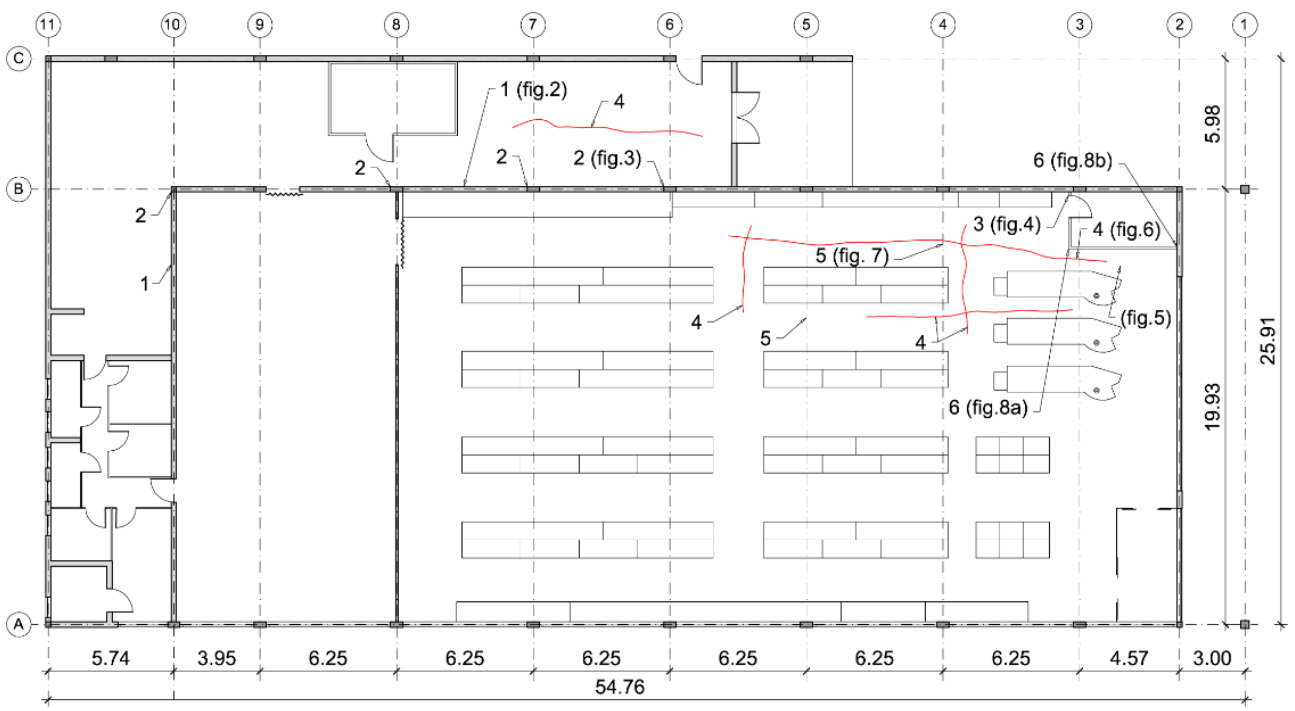

Fig. 9. Structural damage: 1- stepped crack, 2 - crack at the juncture of wall and reinforced concrete core, 3 - crack in non-load-bearing wall, 4 - flooring crack, 5 - tearing of expansion gaps, 6 - damage to the suspended ceiling.

\section{Tests description}

Geodetic measurement of the flooring slope was carried out, 5 core bores were drilled through the flooring (including one through the crack), the compressive strength of the concrete base was tested and geotechnical tests (mechanical drilling, DPL probing) were carried out to establish the causes of damage.

\subsection{Geodetic surveys}

The flooring levels were tested to show the deformation. The tests were carried out in the storage room and the sales room in the areas of the largest deformations (Fig. 10). The test was carried out using a self-levelling level and a levelling rod with millimetre graduation. The measurement accuracy was estimated at $\pm 1.0 \mathrm{~mm}$. In the storage room, the test was carried out over a length of $18 \mathrm{~m}$ and a measuring grid of $1.2 \times 1.2 \mathrm{~m}$ was used. In the sales room, the tests were carried out in the western part over almost the entire length of the room, with a measuring grid of $0.4 \times 0.4 \mathrm{~m}$, this being additionally reduced by half in those areas with the largest deformations. Based on the measurements it was found that the maximum flooring displacement in the night storage room was $5.5 \mathrm{~cm}$, and occurred in the middle of the flooring, while the maximum flooring displacement in the sales room was $7.6 \mathrm{~cm}$ (at the corner of the store manager's room). Graphs with the results are shown in Figs. 11 and 12.

The first test was carried out in July 2015, i.e. 21 months after the commissioning of the structure. Subsequently, the tests were continued at intervals of approx. six-months, until no new impact was found (June 2018). Fig. 13-16 show the changes in flooring deformation recorded during subsequent measurements. These were carried out as linear measurements along the lines shown in Fig. 10. 


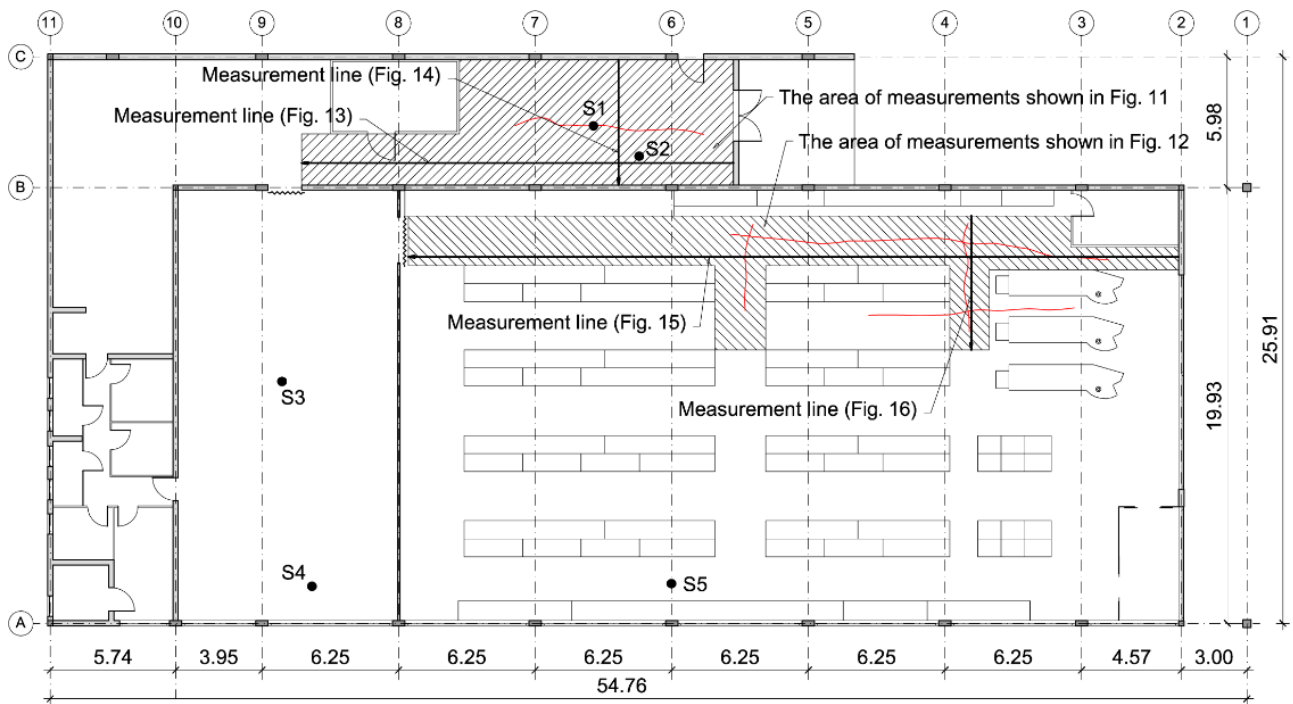

Fig. 10. Locations for geodetic measurements, boreholes and geotechnical tests.

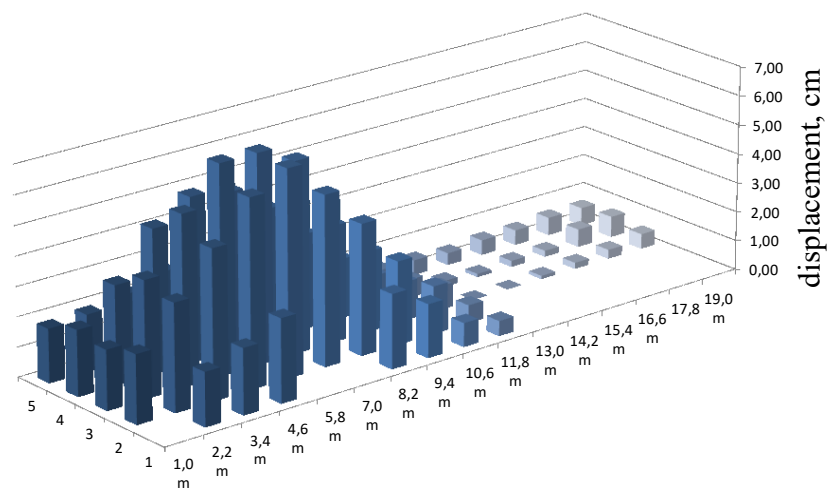

Fig. 11. Flooring deformation tests in the storage room.

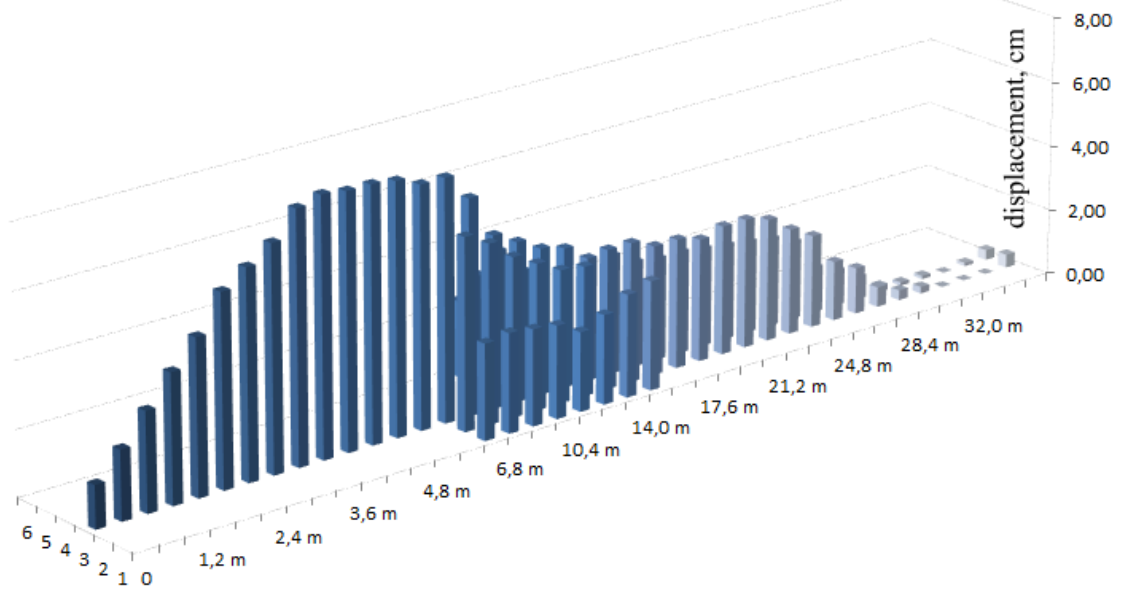

Fig. 12. Flooring deformation tests in the sales room. 


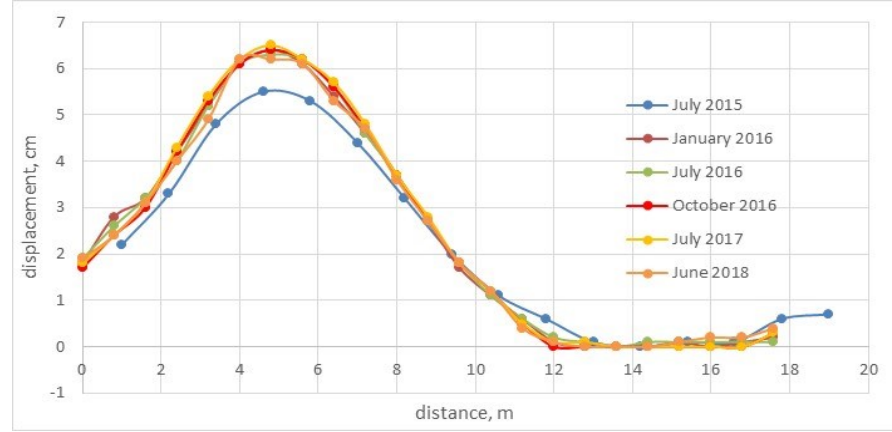

Fig. 13. Results of geodetic measurements in the storage room (longitudinal measurement).

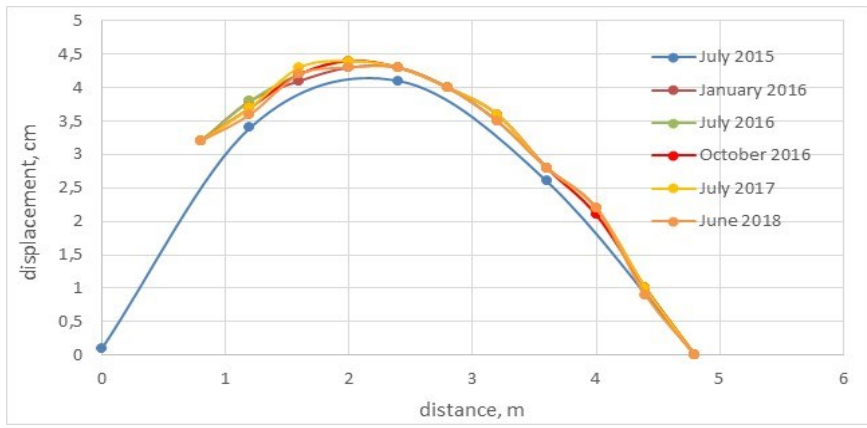

Fig. 14. Results of geodetic measurements in the storage room (transverse measurement).

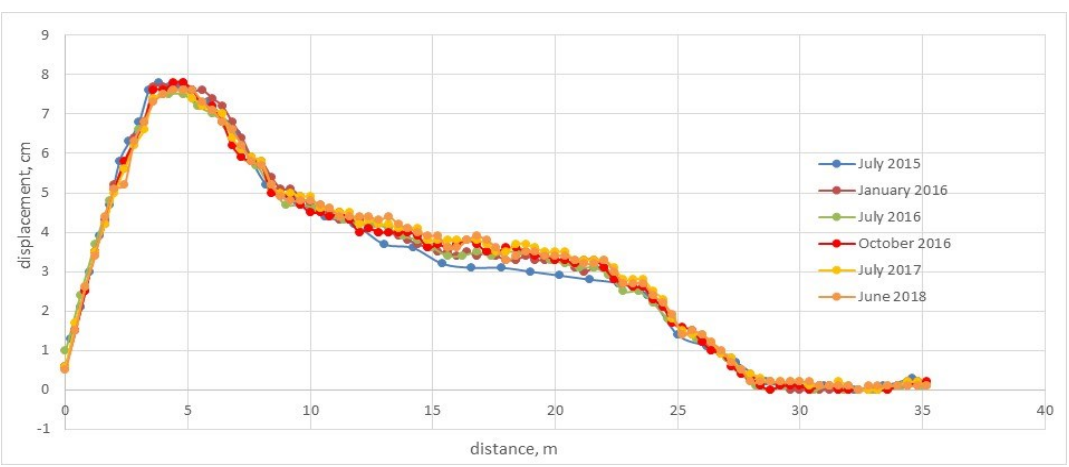

Fig. 15. Results of geodetic measurements in the sales room (longitudinal measurement).

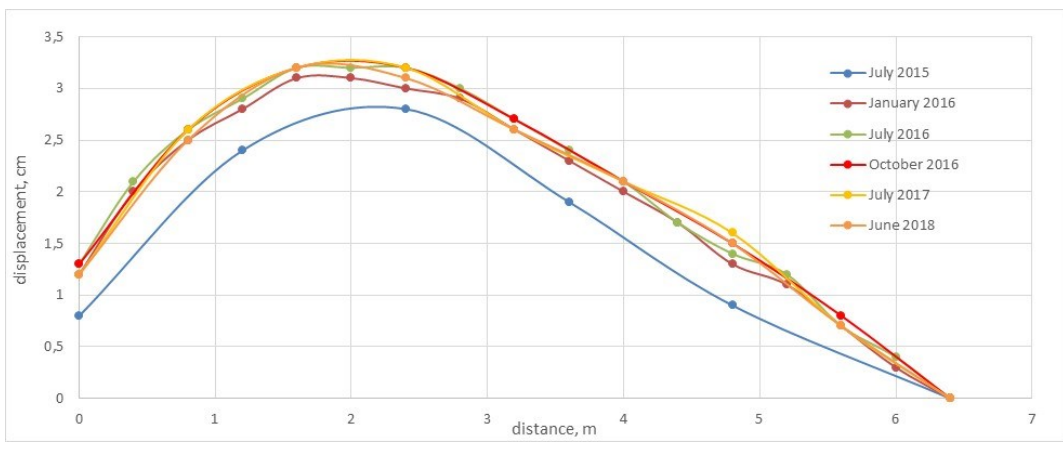

Fig. 16. Results of geodetic measurements in the sales room (transverse measurement). 
Stabilization of the floor deformation was achieved nearly 5 years after its completion. The maximum displacement of the flooring in relation to the lowest measured point in the storage room was $6.2 \mathrm{~cm}$, while the maximum displacement of the flooring in the sales room was $7.8 \mathrm{~cm}$.

\subsection{Core boreholes}

A total of 5 core boreholes, marked S1-S5, were made in the flooring (fig. 10). It was found that the flooring layers were consistent with the design (Fig. 17a). In S1 it was possible to bore through the crack, and it was found that the crack was located in the screed and the upper part of the concrete slab, and was enclosed in the area of half of the sample (Fig. 17b). This indicates the occurrence of a bending condition in the flooring. The strength tests of concrete samples S2-S5 were carried out in accordance with the recommendations [10] and it was found that the concrete grade was consistent with the design.

a)

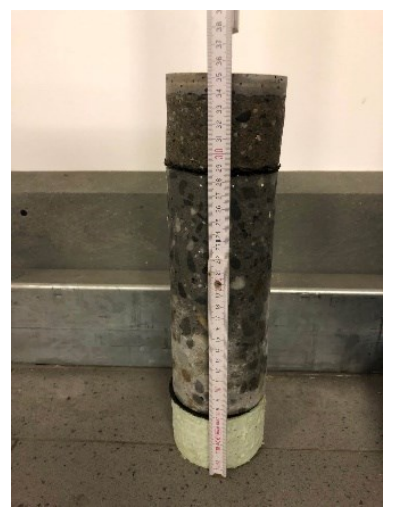

b)

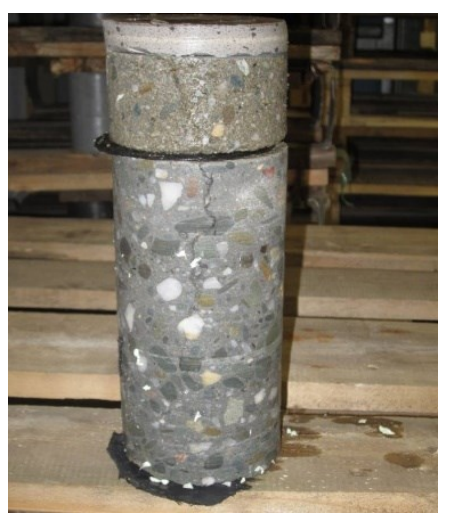

Fig. 17. Samples from core boreholes: a) flooring layers (borehole no. S4), b) cracked sample S1 (the crack runs through the screed and the upper part of the slab).

\subsection{Geotechnical tests}

Geotechnical tests included the identification of the type and condition of the soils underneath the flooring in the holes and under the road surface on the ramp driveway (borehole no. 6). Test drilling and dynamic probing were carried out for that purpose. The drillings were carried out first using hand-held equipment, and it was only possible to determine the type of material used for the flooring foundation. Then, because of the high density of the embankment layers and its partial binding, boreholes were made with specialised equipment. The dynamic probing used a DPL probe, prior to boring. The tests in boreholes no. 1 and 2 (made in the holes left after samples S1 and S2) showed that the substrate comprised:

- foundation layer of dolomite aggregate, approx. $15 \mathrm{~cm}$ thick in a compacted state,

- embankment layer made of unburnt colliery shale mixed with ashes, $1.3 \mathrm{~m}$ thick (borehole no. 1) and $1.4 \mathrm{~m}$ thick (borehole no. 2), locally (borehole no. 2) layered with dolomite aggregate and silty clay, compacted, locally bound,

- residual clay soil, in a stiff/semi-solid state, occurring below the embankment layers down to the depth of drilling.

In boreholes no. 3, 4 and 5, it was found that the flooring was on a layer of condensed dolomite aggregate with a grain size of $0-32 \mathrm{~mm}$ and thickness of $35-40 \mathrm{~cm}$. A medium 
compacted layer $\left(\mathrm{I}_{\mathrm{D}}=63 \%\right)$ of medium sand with a low thickness of few centimetres $(5-8 \mathrm{~cm})$ was found in the upper part of the foundation. Because of the grain size and density of the dolomite, probing in these layers was not possible (lack of DPL probe penetration). Directly under the foundation were embankment layers of cohesive soils mixed with: rock fragments, hard coal, sands of different granulation and concrete rubble. The embankment layers were characterized by a semi-solid state. Their thickness was 1.15-1.3 m. Down to the depth of drilling, the whole was underlain by layers of residual silty clay in a solid state.

Therefore, the tests showed that there was another substrate in the damage area, made of embankments consisting of unburnt colliery shale mixed with ashes, while no shale or ashes were found outside the damage area.

Full contact of the flooring with the soil was found in all boreholes.

\section{Causes of the damage}

At the location of the uneven floor (boreholes no. 1 and 2), the concrete slab was placed on soils of high stiffness. The embankment layers were in a compacted state, partially bonded, and the substrate under them was in a stiff and semi-solid state. As a result, differential settlements could not have occurred in the examined area. This is also confirmed by the full contact (no void sections) between the floor layers and the foundation. In the case of the local occurrence of layers of non-compacted soils, they become susceptible to settling, and at that point the stiffer flooring shows less displacement, resulting in a void section at the junction with the foundation.

In analysing the results of the flooring level tests, it can be observed that the flooring in the storage room and sales room was elevated locally. This is also evidenced by the character of the flooring crack in its upper part - a crack closing downwards. Such a situation can occur only if the soil layers swell under the flooring. The swelling of the soil may be caused by: frost impact on cohesive soil, occurrence of expansive soils in the ground (some clays), rocks made of clay minerals affected by water, and as a result of chemical reactions in anthropogenic soils (e.g. slags, ashes). The impact of frost can be excluded here due to the positive temperatures prevailing in the rooms. There are clays in the substrate, but in the point of largest deformations they were in a semi-solid state (the same as before construction began) and no groundwater was found in their area. The last material under consideration was the mixture of unburnt colliery shale and ashes. According to Gawlicki and Małolepszy [11], some types of ash containing unbound $\mathrm{CaO}$ and $\mathrm{MgO}$ can react with water (e.g. rainwater and/or water supplied during development to achieve optimal humidity), and as a result of hydration there is a slow, but increasing growth in the volume of the material, which may lead to deformation of the top layer of the structure, such as a flooring. Unburnt colliery shales containing clay minerals may also swell under the influence of water supplied to them.

In conclusion, it was found that the cause of damage was the swelling of the soil under the flooring. This is evidenced by the good compaction of the soil, full contact (no void sections) between the flooring layers and the foundation, as well as the nature of the crack and deformation of the flooring.

All damage described in par. 3 was the result of elevation of the flooring, except for the cracks in the masonry walls and at the junctions of walls with reinforced concrete cores. The latter damage was caused by shrinkage of the wall elements. 


\section{Repair}

Three repair options have been proposed:

- Option I. Removal of the flooring with the reinforced concrete slab, correcting the elevated ground of the foundation and its levelling, making a new flooring.

- Option II. Removal of the ceramic tiles. Grinding the underlay for the tiles (max. 2-2.5 cm), laying a self-levelling screed in the remaining area and laying new tiles. If the ground swells have already stabilised, such a procedure would involve increasing the current flooring level by $4-5 \mathrm{~cm}$.

- Option III. Removal of the ceramic tiles in the elevated area. Grinding the underlay for the tiles (max. 2-2.5 cm), laying a screed in the elevated area and creating gentler slopes. Laying new tiles. This repair option would not completely eliminate the flooring slope, only mitigate it. However, the advantage in this case is the limited area of the repair works.

Because the ground deformation is blocked by the reinforced concrete slab, the deformations could increase further if it was weakened by grinding. Therefore, repair option I has been recommended.

\section{Summary}

The article describes the damage to the flooring in a food pavilion in the form of a flooring elevation of up to nearly $8 \mathrm{~cm}$. The flooring elevation was caused by the swelling of the foundation, consisting of embankments made of unburnt colliery shale mixed with ashes. The swelling processes ceased 5 years after the structure was commissioned.

\section{References}

1. Report $n$ r 33: Industrial Floors State-of-the-Art Report (RILEM, Technical Committee TC 184-IFE, 2006)

2. P. Mynarčík, Procedia Eng. 65, pp. 107-112 (2013)

3. D. Qiu, Struct. Eng. 86, pp. 29-37 (2008)

4. Ł. Drobiec, Izolacje, 1, pp. 52-58 (2017) [in Polish]

5. M. Gajzler, Engineering Struc. a. Techn., 8, pp. 8-14 (2016)

6. R. Jasiński , Ł. Drobiec, A. Piekarczyk. Procedia Eng. 161, pp. 904-910 (2016)

7. R. Jasiński , Ł. Drobiec, A. Piekarczyk. Procedia Eng. 161, pp. 911-917 (2016)

8. Ł. Drobiec. Mauerwerk, 21, pp. 332-342 (2017)

9. Ł. Drobiec, R. Jasiński, W. Mazur. Cement Wapno Beton, 5, pp. 339-413 (2017) [in Polish]

10. Ł. Drobiec, R. Jasiński, A. Piekarczyk, Diagnostic testing of reinforced concrete structures. Methodology, field tests, laboratory tests of concrete and steel. (Scientific Company PWN, Warsaw, 2010) [in Polish]

11. M. Gawlicki, J. Małolepszy, Potential hazards of utilizing industrial waste in road construction projects (Proceedings of XXVI Scientific-Technical Conference on Structural Failures, Szczecin-Międzyzdroje, pp. 23-38, 2013) [in Polish] 